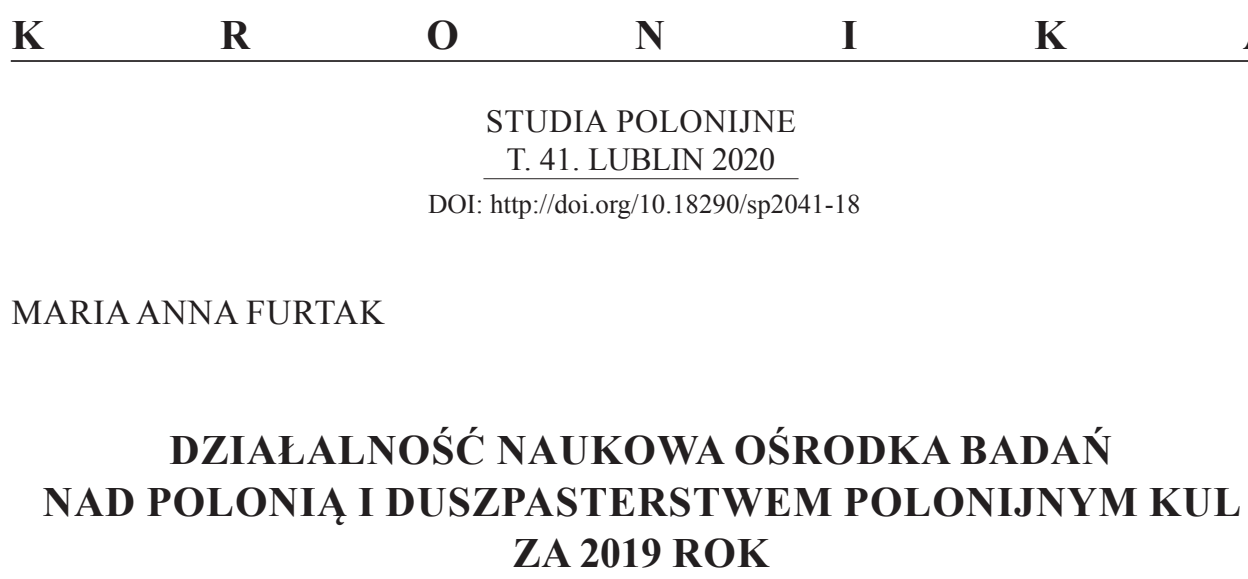

W roku 2019 Ośrodek funkcjonował w następującym składzie: dr hab. Jacek Gołębiowski, prof. KUL, adiunkt ks. dr hab. Sławomir Zych, dr Paweł Sieradzki (od 1.10.2019 - dokumentalista). Funkcję redaktora naczelnego „Studiów Polonijnych” pełnił ks. dr hab. Sławomir Zych. Stałym współpracownikiem Ośrodka była mgr Maria Anna Furtak, doktorantka Instytutu Historii KUL, od czerwca 2019 r. sekretarz redakcji „Studiów Polonijnych”.

\title{
PROJEKTY BADAWCZE
}

Główna działalność pracy Ośrodka skupiała się na realizacji grantu NPRH „Polish Cathedrals - polskie dziedzictwo religijne, kulturowe, społeczne i materialne w Stanach Zjednoczonych. Leksykon". W ramach prac naukowych prof. J. Gołębiowski i dr P. Sieradzki przeprowadzili 5-miesięczne kwerendy na terenie USA (stany Wisconsin, Illinois, Pensylwania, Maryland, Minnesota, Nowy York, Connecticut), w archiwach m.in. diecezjalnych, miejskich, uniwersyteckich i parafialnych. Rozpoczęto opracowywanie pozyskanych materiałów. Część z nich ukaże się w formie artykułów naukowych i monografii w roku 2020.

Kontynuowano projekt „Parafie i kościoły polskie w USA - inwentaryzacja fotograficzna i źródłowa”, sfinansowany ze środków Ministra Kultury i Dziedzictwa Narodowego w ramach zadania „Ochrona dziedzictwa kulturowego za granicą 2019”. III etap projektu rozpoczął się w kwietniu 2019 r., badaniami objęto polskie kościoły w Milwaukee, Philadelphii, Syracuse i Baltimore, przeprowadzono inwentaryzację fotograficzną. 17 grudnia 2019 odbyła się sesja naukowa podsumowująca prowadzony od 2017 r. projekt. Brali w niej udział pracownicy Ośrodka Badań nad Polonią

Mgr Maria AnNa FurtaK - Instytut Historii na Wydziale Nauk Humanistycznych Katolickiego Uniwersytetu Lubelskiego Jana Pawła II; e-mail: furtakma@gmail.com. ORCID: https://orcid. org/0000-0002-4797-9135 
oraz uczestnicy projektu z Uniwersytetu Kardynała Stefana Wyszyńskiego. Kierownik projektu, prof. Jacek Gołębiowski dokonał podsumowania prac podejmowanych w ciągu ostatnich trzech lat na terenie Stanów Zjednoczonych. W ich wyniku przeprowadzono kwerendy źródłowe i inwentaryzacyjne w ponad 50 polskich kościołach, pozyskując w ten sposób obszerny materiał badawczy. Digitalizacją objęto dziesiątki ksiąg jubileuszowych, biuletynów parafialnych oraz różnego rodzaju dokumentów. Równocześnie przeprowadzono dokumentację fotograficzną badanych obiektów, której celem było utrwalenie piękna architektury i sztuki polskich kościołów w Stanach Zjednoczonych.

\section{DZIAŁALNOŚĆ NAUKOWA I POPULARYZATORSKA}

Prof. Jacek Gołębiowski brał udział w audycjach Tv Trwam w Chicago i TVP Polonia poświęconych dziedzictwu polskiemu w USA.

Dr Paweł Sieradzki wygłosił referat podczas sesji zorganizowanej przez Komisję Episkopatu Polski pt. „Rola duszpasterzy polonijnych wobec polskiego dziedzictwa religijnego w świecie”, oraz brał udział w audycjach w Radiu Maryja i Tv Trwam („Rola Polonii amerykańskiej w odzyskaniu niepodległości Polski”; „Dziedzictwo religijne Polonii amerykańskiej").

Ks. dr hab. Sławomir Zych wygłosił referat na sympozjum, rozpoczął kwerendę „Dziennika Chicagoskiego”, oraz prowadził badania w archiwach archidiecezji przemyskiej, diecezji rzeszowskiej i wielu parafialnych.

Pracownicy Ośrodka przeprowadzili ponadto kwerendy w polskich archiwach, m.in. parafii w Leżajsku, Jarosławiu, Łańcucie, Bibliotece im. Ossolińskich we Wrocławiu. Brali również udział w zajęciach w ramach Akademii Młodych Humanistów.

Działalność Ośrodka była tematem jednego z reportaży w programie TVP Lublin „Login: Nauka”, wyemitowanego 5 lutego 2019 r.

29 stycznia 2019 ks. dr hab. Sławomir Zych został odznaczony brązowym Krzyżem Zasługi, natomiast 26 marca 2019 otrzymał nominację od Walnego Zebrania Towarzystwa Naukowego KUL na członka korespondenta Wydziału Historyczno-Filologicznego TN KUL 26 marca 2019 r.

\section{PUBLIKACJE}

Wysoka k. Łańcuta: studia, szkice i materiaty z dziejów parafii i miejscowości, t. II, red. Adam Szal, Sławomir Zych, Wysoka: Wydawnictwo Archidiecezji Przemyskiej 2019

„Studia Polonijne” 40 (2019), ss. $422+7 \mathrm{nlb}$

„Rocznik Kolbuszowski” 19 (2019), ss. $420+2 \mathrm{nlb}$ 
MARIAN BRUDZISZ CSsR, Udziat redemptorystów polskich w odrodzeniu Kościoła rzymskokatolickiego na Białorusi, Lublin-Kraków: Homo Dei 2019

„Studia Polonijne” otrzymały dofinansowanie w ramach programu Ministerstwa Nauki i Szkolnictwa Wyższego „Wsparcie dla czasopism naukowych”. 